\title{
Inheritance and Interactions of Necrotic, Mottled, and Resistant Reactions to Lettuce Mosaic Virus in Lettuce
}

\author{
Edward J. Ryder \\ U.S. Department of Agriculture, Agricultural Research Service, 1636 East Alisal Street, Salinas, CA 93905
}

\begin{abstract}
AdDitional INDEX WORDs. Lactuca sativa, resistance, mottling, seed transmission, green peach aphid, Myzus persicae, epistasis

Abstract. Segregation data from crosses between necrotic and mottled lettuce (Lactuca sativa L.) parents showed that a single gene controls the difference in type of reaction to lettuce mosaic virus: necrosis is dominant to mottled. Segregation data from crosses between resistant and necrotic parents differed, depending on the necrotic parent. In crosses with the necrotic cultivar Prizehead, there were two independent genes, one controlling necrotic vs. mottled and the other resistant vs. susceptible. In a cross with the necrotic cultivar Maikonig, resistance was epistatic to necrotic, suggesting a second necrotic allele. Crosses among necrotic cultivars indicated a single gene for the necrotic reaction, with the possibility of more than one necrotic allele. Necrotic alleles identified are named Necrotic- $1^{m}$ and Necrotic-1 ${ }^{p}$.
\end{abstract}

Most lettuce (Lactuca sativa) cultivars are susceptible to infection by the virus that causes lettuce mosaic in cultivated lettuce, related wild species, and species in several other genera (Ryder 1968). The typical systemic sequence of reaction in susceptible cultivars of lettuce begins with vein clearing on the first expressing leaf, followed by mottling on subsequent leaves (Fig. 1). These symptoms are accompanied by recurving of the leaf margin and an increase in the degree of frilliness of the margin. The growth of the plant is retarded. Plants affected early become stunted when mature, with a metallic cast to the leaves. There may also be yellowed or necrotic areas. Bolting plants may have necrotic areas on the seed stalk, cauline leaves, and involucre bracts. Seed production is drastically reduced and the virus is seedborne in a small proportion of the seeds that do form (Newhall, 1923).

Necrosis may occur as a direct and immediate reaction to infection by lettuce mosaic virus (LMV) in at least three ways. Some strains of the virus cause a necrotic reaction in plants that would normally become mottled when infected by a mottling strain. Zink et al. (1973) described a virulent strain of LMV found in a planting of 'Great Lakes 65'. This strain induced severe necrosis and was highly lethal. Pink et al. (1992) compared five isolates (LMV-W, LMV-F, LMV-G, LMV-YAR, and LMV-E) for their effect on symptom expression, as well as on yield and marketability of susceptible and resistant cultivars. LMV-E was highly virulent and caused necrotic symptoms on both resistant and susceptible cultivars. Recent work by Redondo et al. (2001) suggests that the severe effect of the LMV-E isolate is caused by a protein, HC-Pro, coded by the viral DNA.

We have observed that some cultivars of lettuce, such as the crisphead cultivar, Vanguard, react with necrosis under winter conditions in the greenhouse, whereas they would produce standard mottling symptoms in warm weather and under long day conditions. Finally, some cultivars react with varying degrees of necrosis in immediate response to infection by a standard mottling isolate (Fig. 1). The last reaction type is discussed in this paper as a genetic phenomenon.

In a preliminary survey, the following cultivars showed necrotic reactions that varied in severity, distribution, and time to symptom expression: Crisphead-'Hanson', 'Imperial D',

Received for publication 14 May 2001. Accepted for publication 22 OCt. 2001. This work was supported in part by the California Lettuce Research Board. Thanks to David J. Milligan for technical assistance.
'Batavia Blonde de Paris', 'Green Mignonette', 'Jade', 'Mignonette Bronze'; Butterhead-'Maikonig', 'Crisp As Ice', 'Bibb', 'Crispheart', 'Dark Green Boston', 'Hubbard's Market', 'Liba', 'Regina', 'Ventura', 'Wonder van Voorburg'; Cos—'Balloon', Eiffel Tower', 'Lobcross' , 'Red Hot Cos' Red leaf-'Prizehead', 'Big Red', 'Deep Red', 'Red Line', 'Western Red Leaf'; Green leaf-'Deer's Tongue', 'Oakleaf'; Stem-'Celtuce'.

An early discussion of necrosis associated with LMV was part of a study on virus seed transmission (Couch 1955). The cultivar, Cheshunt Early Giant, showed no seed transmission from infected plants. Plants of this cultivar were severely damaged by the virus, with necrosis occurring at all growth stages. The tissues of the primary floral shoot were severely damaged, yielding no seed. However, seed was produced on secondary shoots and the level of viral activity was considerably reduced, leading to a tentative conclusion that there was insufficient virus in the secondary shoots to infect the developing seeds.

Simply inherited recessive resistance to LMV has been identified (Ryder 1968, Von der Pahlen and Crnko 1965). The reaction is systemic, manifested by chlorotic lesions, which vary in size and number or may be absent (Fig. 2). There is little distortion or stunting. Expression varies with season or growth stage of the plant at the time of inoculation. This type of resistance is best described as resistance to virus increase and spread (Bjorling 1966).

This study was undertaken to further elucidate the complex relationship between LMV and lettuce and its relatives. It examines the genetic basis for induction of a necrotic reaction in certain genotypes against the standard mottling strain of LMV.

\section{Materials and Methods}

Four of the cultivars manifesting a necrotic reaction as the primary early response to inoculation with LMV were crossed with cultivars showing a typical mottling reaction, cultivars showing a resistant reaction, and other cultivars showing a necrotic reaction (Table 1 ). The necrotic reaction varied among cultivars and represents a sample of the variation observed among a number of cultivars and plant introduction (PI) accessions.

The crosses between necrotic and mottled cultivars included 'Salinas' X 'Prizehead', 'Salinas' x 'Crisp As Ice', and 'Salinas' $x$ 'Deer's Tongue'. The crosses between necrotic and resistant parents included PI 251245 x 'Prizehead', 'Vanguard 75' x 'Prizehead', and 'Salinas 88' x 'Maikonig'. The crosses among 


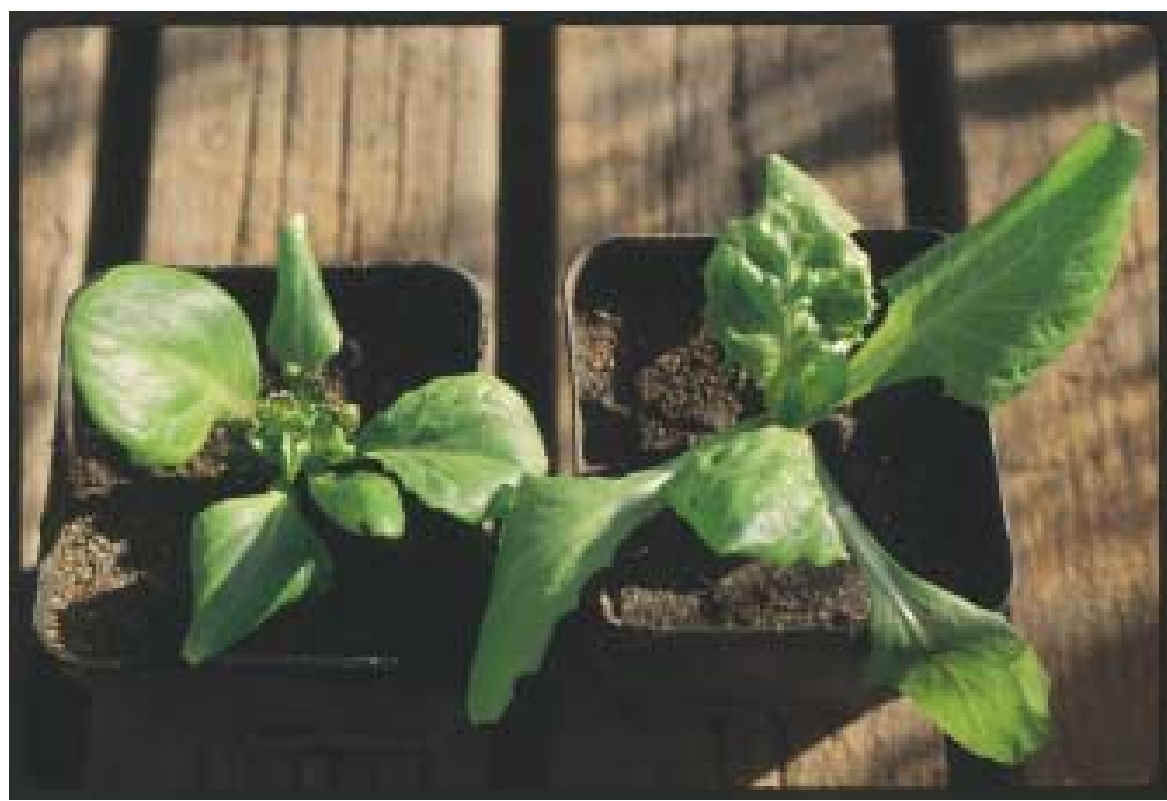

Fig. 1. Effect of lettuce mosaic virus on $\mathrm{F}_{2}$ plants from 'Salinas' $\mathrm{X}$ 'Crisp As Ice' Necrotic reaction (left) and mottled reaction (right).

necrotic cultivars were between 'Prizehead' and other necrotic cultivars, including 'Crisp As Ice', 'Deer's Tongue', 'Balloon', 'Hanson', 'Eiffel Tower', 'Imperial D', and 'Lobcross'.

Plants were seeded in plastic pots in $450 \mathrm{~mL}$ of a 2 soil : 1 sand medium (by volume) and inoculated with the virus at $18 \mathrm{~d}$ after seeding, at about the three to four leaf stage. The plants were transplanted to pots filled with $400 \mathrm{~mL}$ of soil. No supplemental fertilization was done. All experiments were conducted in a greenhouse under ambient light and relative humidity conditions. Temperature was partially controlled with evaporative coolers set at 29.4 in warmer days and with hot water heaters set at 18.3 ${ }^{\circ} \mathrm{C}$ for cold nights. The virus strain used in all experiments was a single strain collected from a plant in a lettuce field in the Salinas Valley of California in 1958. It has been maintained in the greenhouse by plant to plant transfer since then, and no detectable change has been noted. After inoculation, the plants were transplanted singly to pots filled with soil.

All plant groups were vector-inoculated with the green peach aphid (Myzus persicae Sulz.), raised on White Icicle radish (Raphanus sativus L.), transferred for $24 \mathrm{~h}$ to feed on LMV infected plants of 'Vanguard' lettuce, and then transferred to test plants at the three- to four-leaf stage of growth. Plants that showed no symptoms were reinoculated.

Plants were observed for symptom expression in the parental, $F_{1}, F_{2}$, and $F_{3}$ generations. In some cases, $\mathrm{F}_{3}$ escapes were grown to seed and $\mathrm{F}_{4}$ progenies were observed.

Plants were classified according to symptom type (Figs. 1 and 2). Ratios of symptom classes were analyzed by chi square for goodness of fit to expected ratios according to hypothesis.

\section{Results}

Crosses between necrotic and mottled parents

'Salinas' $x$ 'Prizehead'. The $\mathrm{F}_{1}$ was necrotic. The $F_{2}$ population segregated $\approx 3$ necrotic : 1 mottled (Table 2 ). $\mathrm{F}_{3}$ families from both classes of $F_{2}$ plants segregated $\approx 1$ all necrotic : 2 segregating : 1 all mottled. Within the segregating $\mathrm{F}_{3}$ families, there was an excess of mottled plants, based upon the expectation of a 3:1 ratio as in the $F_{2}$. The poor ratio in segregating $\mathrm{F}_{3}$ families of this cross may have been due to misreading of symptoms in three of the 11 families evaluated. If the results from those three families are set aside, segregation is as expected.

'SAlinas' $x$ 'CRISP As ICE'. The $\mathrm{F}_{1}$ was necrotic. The $F_{2}$ population segregated $\approx 3$ necrotic : 1 mottled (Table 2 ). Two plantings of $\mathrm{F}_{3}$ families segregated $\approx 1$ all necrotic : 2 segregating : 1 all mottled. Within segregating $\mathrm{F}_{3}$ families, segregation was close to 3 necrotic : 1 mottled, as expected.

'Deer's Tongue' $x$ 'Salinas'. The $\mathrm{F}_{1}$ was necrotic. The $\mathrm{F}_{2}$ population segregated $\approx 3$ necrotic : 1 mottled (Table 2). $F_{3}$ families segregated $\approx 1$ all necrotic $: 2$ segregating : 1 all mottled, and within segregating $\mathrm{F}_{3}$ families, the ratio was $\approx 3$ necrotic $: 1$ mottled, again as expected.

Results in all three crosses indicate single gene inheritance. Necrotic is dominant to mottled.

\section{Crosses between necrotic and resistant parents}

'Vanguard 75' x 'Prizehead'. The $\mathrm{F}_{1}$ was necrotic. Four phenotypes appeared in the $\mathrm{F}_{2}$ generation (Table 3 ). In addition to the parental phenotypes, resistant and necrotic, there were plants that were mottled and plants showing a resistant symptom with a

Fig. 2. Effect of lettuce mosaic virus on a resistant lettuce plant, showing chlorotic lesion, top left of center leaf.

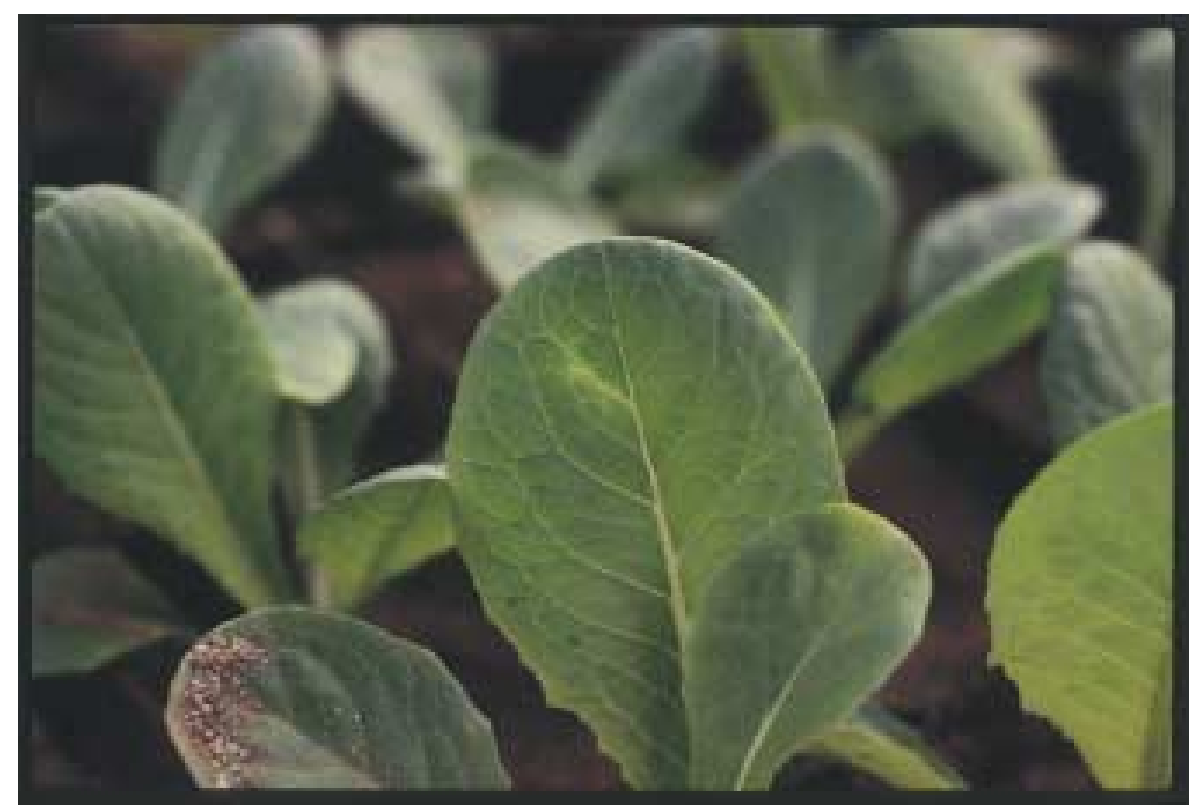


Table 1. Cultivars and lines of lettuce used as parents in crosses described in this paper and symptom produced when inoculated with lettuce mosaic virus.

\begin{tabular}{lll}
\hline \hline Cultivar/line & Type & Symptom \\
\hline Salinas & Crisphead & Mottle \\
Prizehead & Red leaf & Necrotic \\
Crisp As Ice & Red butterhead & Necrotic \\
Deer's Tongue & Green Leaf & Necrotic \\
Maikonig & Butterhead & Necrotic \\
Balloon & Cos & Necrotic \\
Hanson & Crisphead & Necrotic \\
Imperial D & Crisphead & Necrotic \\
Eiffel Tower & Cos & Necrotic \\
Lobcross & Cos & Necrotic \\
Salinas 88 & Crisphead & Resistant \\
Vanguard 75 & Crisphead & Resistant \\
PI 251245 & Primitive & Resistant \\
\hline
\end{tabular}

small necrotic spot. The four phenotypes appeared in a ratio of $\approx 9$ necrotic : 3 mottled : 3 resistant-necrotic : 1 resistant.

PI 251245 x 'Prizehead'. The $F_{1}$ was necrotic. Two parental and two recombinant phenotypes appeared in the $F_{2}$ population, which segregated $\approx 9$ necrotic $: 3$ mottled : 3 resistant-necrotic : 1 resistant (Table 3).

The number of $\mathrm{F}_{3}$ families from each cross was relatively small. The resistance allele in 'Vanguard 75' is derived from PI 251245, and 'Prizehead' was the necrotic parent in both crosses. Therefore $\mathrm{F}_{3}$ families from each group were combined for confirmation of $\mathrm{F}_{2}$ results (Table 3 ).

$\mathrm{F}_{3}$ families from necrotic $\mathrm{F}_{2}$ plants were all necrotic, segregating necrotic and mottled, segregating necrotic and resistantnecrotic, or segregating as in the $F_{2}$. The ratio of classes was $\approx 1: 2: 2: 4$, as expected. Families from mottled $\mathrm{F}_{2}$ plants segregated 1 mottled : 2 mottled and resistant, as expected. The ratio of families from resistant-necrotic $\mathrm{F}_{2}$ plants was $\approx 1$ all resistantnecrotic : 2 resistant-necrotic and resistant, as expected. Resistant $\mathrm{F}_{2}$ plants produced all resistant progenies.

Within segregating $F_{3}$ families, the segregation ratios are expected to be $9: 3: 3: 1$, as in the $\mathrm{F}_{2}$, where all four phenotypes are expected and 3:1 for the single gene segregations. The single gene segregations necrotic:mottled, necrotic:resistant-necrotic, necrotic-resistant:resistant, and mottled:resistant all were $\approx 3: 1$ (Table $3)$. However, the four class segregation ratio did not fit the expected 9:3:3:1 well. There was a severe shortage of resistantnecrotic plants in both crosses and in the total. Resistant-necrotic plants may have been misread as either resistant or necrotic.

Results of these two crosses support the presence of a single gene for necrotic reaction that is inherited with no indication of linkage to the Momo gene (mottled vs resistant, Ryder 1970), based on the relatively small populations grown. There is also no indication of epistasis.

'SaLINas 88' x 'MaIKonig'. The $F_{1}$ was necrotic. In addition to the two expected phenotypes in the $F_{2}$ population, there was a new phenotype, mottled (Table 4). The three phenotypes segregated in the ratio 9 necrotic : 3 mottled : 4 resistant. Considering the possibility that the fourth phenotype found in the crosses with 'Prizehead', resistant-necrotic, may have been missed in this study, a second $F_{2}$ population was grown, and segregated $\approx 9: 3: 4$, as in the first population.

$\mathrm{F}_{3}$ families segregated all necrotic, necrotic and mottled, all mottled, necrotic and resistant, mottled and resistant, all resistant, and necrotic, mottled, and resistant in a ratio of $\approx 1: 2: 1: 2: 2: 4: 4$ (Table 4). Within segregating $F_{3}$ families, segregation was $\approx 9: 3: 4$ as in the $\mathrm{F}_{2}$, or 3:1 in single trait segregating families.

The evidence again suggests two genes operating, but with an epistatic effect such that the resistance allele overrides the effect of the necrotic allele. This also suggests that the necrotic allele from 'Maikonig' is not the same as in 'Prizehead'.

\section{Crosses between necrotic and necrotic parents}

The cross 'Prizehead' X 'Crisp As Ice' produced a necrotic F $F_{1}$; all plants in the $F_{2}$ population were also necrotic. This suggests that the necrosis in each cultivar is due to an allele of the same gene. It is possible that the alleles are different, but the similarity in symptom expression suggests they are the same. The cross 'Deer's Tongue' $x$ 'Prizehead' also produced a necrotic $F_{1}$ and all necrotic plants in the $F_{2}$. This also suggests the same gene.

Table 2. Segregation for lettuce mosaic symptom expression in three populations from crosses between mottled and necrotic lettuce parents.

\begin{tabular}{|c|c|c|c|c|c|}
\hline Population & Necrotic & Segregation & Mottled & $\chi^{2}$ & $P$ \\
\hline \multicolumn{6}{|l|}{$\overline{\mathrm{F}_{2}(\text { Expect } 3: 1)}$} \\
\hline Salinas x Prizehead & 47 & & 16 & 0.01 & $0.90-0.95$ \\
\hline Salinas x Crisp As Ice & 49 & & 17 & 0.02 & $0.80-0.90$ \\
\hline Deer's Tongue x Salinas & 26 & & 9 & 0.01 & $0.90-0.95$ \\
\hline Pooled & 122 & & 42 & 0.03 & $0.80-0.90$ \\
\hline Heterogeneity (2 df) & & & & 0.004 & $>0.99$ \\
\hline \multicolumn{6}{|c|}{ Among $\mathrm{F}_{3}$ families (Expect $1: 2: 1$ ) } \\
\hline Salinas x Prizehead & 12 & 24 & 12 & 0 & $>0.99$ \\
\hline Salinas $\times$ Crisp As Ice (1) & 7 & 13 & 3 & 1.79 & $0.30-0.50$ \\
\hline Salinas $x$ Crisp As Ice (2) & 9 & 25 & 10 & 0.86 & $0.50-0.70$ \\
\hline Deer's Tongue $x$ Salinas & 5 & 16 & 9 & 1.20 & $0.70-0.80$ \\
\hline Pooled & 33 & 78 & 34 & 0.84 & $0.50-0.70$ \\
\hline Heterogeneity (3 df) & & & & 3.00 & $0.30-0.50$ \\
\hline \multicolumn{6}{|c|}{ Within segregating $\mathrm{F}_{3}$ families (Expect $3: 1$ ) } \\
\hline Salinas x Prizehead & 51 & & 38 & 14.87 & $<0.01$ \\
\hline Salinas x Crisp As Ice & 283 & & 101 & 0.35 & $0.50-0.70$ \\
\hline Deer's Tongue $\mathrm{x}$ Salinas & 172 & & 68 & 1.43 & $0.20-0.30$ \\
\hline Pooled & 506 & & 207 & 6.19 & $0.01-0.02$ \\
\hline Heterogeneity (2 df) & & & & 10.46 & $<0.01$ \\
\hline
\end{tabular}


Table 3. Segregation for lettuce mosaic symptom expression in two populations from crosses between resistant $(\mathrm{R})$ and necrotic $(\mathrm{N})$ lettuce parents $(\mathrm{M}=$ mottled).

\begin{tabular}{|c|c|c|c|c|c|c|}
\hline Population & $\mathrm{N}$ & M & $\mathrm{R}-\mathrm{N}$ & $\mathrm{R}$ & $\chi^{2}$ & $p$ \\
\hline \multicolumn{7}{|l|}{$\overline{F_{2}(\text { expect } 9: 3: 3: 1)}$} \\
\hline Vanguard $75 \times$ Prizehead & 40 & 8 & 8 & 3 & 3.23 & $0.30-0.50$ \\
\hline PI 251245 x Prizehead & 66 & 20 & 25 & 9 & 0.62 & $0.90-0.95$ \\
\hline Pooled & 106 & 28 & 33 & 12 & 1.27 & $0.70-0.80$ \\
\hline Heterogeneity (1 df) & & & & & 2.58 & $0.10-0.20$ \\
\hline \multicolumn{7}{|l|}{ Among $\mathrm{F}_{3}$ families } \\
\hline Cross & Vanguard $75 \times$ Prizehead & & PI 251245 x Prizehead & & Total & \\
\hline \multicolumn{7}{|c|}{ From $\mathrm{N} \mathrm{F}_{2}$ plants (expect $1: 2: 2: 4$ ) } \\
\hline All N & 3 & & 5 & & 8 & \\
\hline $\mathrm{N}: \mathrm{M}$ & 3 & & 12 & & 15 & \\
\hline$N: R-N$ & 3 & & 8 & & 11 & \\
\hline Segregating like $\mathrm{F}_{2}$ & 13 & & 19 & & 32 & \\
\hline$\chi^{2}$ & & & & & 1.25 & \\
\hline$P$ & & & & & $0.70-0.80$ & \\
\hline \multicolumn{7}{|l|}{ From $\mathrm{M} \mathrm{F}_{2}$ plants (expect $1: 2$ ) } \\
\hline All M & 0 & & 4 & & 4 & \\
\hline $\mathrm{M}: \mathrm{R}$ & 2 & & 5 & & 7 & \\
\hline$\chi^{2}$ & & & & & 0.04 & \\
\hline$P$ & & & & & $0.80-0.90$ & \\
\hline \multicolumn{7}{|l|}{ From R-N F ${ }_{2}$ plants (expect 1:2) } \\
\hline All R-N & 3 & & 7 & & 10 & \\
\hline $\mathrm{R}-\mathrm{N}: \mathrm{R}$ & 8 & & 16 & & 24 & \\
\hline$\chi^{2}$ & & & & & 0.24 & \\
\hline$P$ & & & & & $0.50-0.70$ & \\
\hline \multicolumn{7}{|c|}{ Within segregating $F_{3}$ families (expect $9: 3: 3: 1$ or $3: 1$ ) } \\
\hline Classes & $\mathrm{N}$ & M & $\mathrm{R}-\mathrm{N}$ & $\mathrm{R}$ & $\chi^{2}$ & $P$ \\
\hline $\mathrm{N}: \mathrm{M}: \mathrm{R}-\mathrm{N}: \mathrm{R}$ & 354 & 126 & 81 & 46 & 12.94 & $<0.01$ \\
\hline $\mathrm{N}: \mathrm{M}$ & 196 & 68 & & & 0.08 & $0.70-0.80$ \\
\hline $\mathrm{N}: \mathrm{R}-\mathrm{N}$ & 134 & & 38 & & 0.77 & $0.30-0.50$ \\
\hline $\mathrm{R}-\mathrm{N}: \mathrm{R}$ & & & 146 & 64 & 3.79 & $0.05-0.10$ \\
\hline MM:R & & 60 & 21 & & 0.04 & $0.80-0.90$ \\
\hline
\end{tabular}

Table 4. Segregation ratios for lettuce mosaic reaction in the cross 'Salinas $88^{\prime}$ ' 'Maikonig' $(N=$ necrotic, $R=$ resistant, $M=$ mottled).

\begin{tabular}{|c|c|c|c|c|c|}
\hline Population & $\mathrm{N}$ & $\mathrm{M}$ & $\mathrm{R}$ & $\chi^{2}$ & $P$ \\
\hline \multicolumn{6}{|l|}{ Expect 9:3:4 } \\
\hline $\mathrm{F}_{2}-1$ & 38 & 16 & 18 & 0.61 & $0.70-0.80$ \\
\hline $\mathrm{F}_{2}^{2}-2$ & 41 & 10 & 12 & 2.05 & $0.30-0.50$ \\
\hline Pooled & 79 & 26 & 30 & 0.56 & $0.70-0.80$ \\
\hline Heterogeneity (2 df) & & & & 2.10 & $0.30-0.50$ \\
\hline \multicolumn{6}{|c|}{ Among $\mathrm{F}_{3}$ families (expect $1: 2: 1: 2: 2: 4: 4$ ) } \\
\hline All N & 2 & $\mathrm{M}: \mathrm{R}$ & 3 & & \\
\hline $\mathrm{N}: \mathrm{M}$ & 6 & All R & 9 & & \\
\hline All M & 4 & $\mathrm{~N}: \mathrm{M}: \mathrm{R}$ & 9 & & \\
\hline $\mathrm{N}: \mathrm{R}$ & 4 & & & & \\
\hline $\begin{array}{l}\chi^{2}=2.37 \\
P=0.70-0.80\end{array}$ & & & & & \\
\hline
\end{tabular}

Within segregating $\mathrm{F}_{3}$ families (expect 9:3:4 or 3:1)

\begin{tabular}{lccrr} 
Classes & $\mathrm{N}$ & $\mathrm{M}$ & $\mathrm{R}$ & $\chi^{2}$ \\
\hline $\mathrm{N}: \mathrm{M}: \mathrm{R}$ & 85 & 32 & 32 & 1.35 \\
$\mathrm{~N}: \mathrm{N}$ & 67 & 20 & & $0.50-0.70$ \\
$\mathrm{~N}: \mathrm{R}$ & 36 & & 11 & 0.64 \\
$\mathrm{M}: \mathrm{R}$ & & 21 & $9.30-0.50$ & 0.07 \\
\hline
\end{tabular}


'Prizehead' was crossed with five other cultivars with a necrotic reaction to LMV: 'Balloon', 'Hanson', 'Imperial D', 'Eiffel Tower', and 'Lobcross'. In all crosses, $\mathrm{F}_{1}$ and $\mathrm{F}_{2}$ populations were all necrotic, indicating the same gene but not necessarily the same allele for necrosis.

\section{Discussion}

Data from the cross 'Salinas' $x$ 'Prizehead' indicate the effect of a single gene, with necrotic dominant to mottled, which may be due to an allele of $M o-1$, or to an allele at another locus. Crosses of 'Prizehead' and the resistant parents 'Vanguard 75' and PI 251245 produced a mottled phenotype, which is only possible if 'Prizehead' has both the MoMo genotype and a second gene for the necrotic effect.

Data from the cross 'Salinas' $x$ 'Crisp As Ice' also indicate the effect of a single gene. The cross 'Prizehead' $x$ 'Crisp As Ice' produced only necrotic progeny in the $\mathrm{F}_{2}$ population, suggesting that the two necrotic cultivars have the same necrotic allele. However, data from another cross suggest otherwise. Three $F_{2}$ populations from the cross 'Vanguard' $x$ 'Crisp As Ice', grown at different times, segregated with a preponderance of mottled plants, suggesting that the mottled effect in 'Vanguard' is dominant to necrotic in 'Crisp As Ice'. On the other hand, $\mathrm{F}_{2}$ populations from the crosses 'Kingsholm' $x$ 'Crisp As Ice', 'Kingsholm' $\mathrm{x}$ 'Prizehead', and 'Vanguard' $\mathrm{x}$ 'Prizehead' all segregate with a predominance of necrotic plants. Furthermore, both 'Vanguard' and 'Kingsholm' react necrotically in winter under short days and lower temperature regimes. Therefore, it is possible that two mottled alleles and two necrotic alleles may be operating in these crosses. In any case, it appears likely that the 'Crisp As Ice' allele is different from the 'Prizehead' allele.

Data from the crosses between resistant and necrotic parents also confirm the action of a single gene for necrotic versus mottled. In the crosses with 'Prizehead', the necrotic gene acts independently of the mottle gene, giving the classic ratio 9:3:3:1 for independent assortment. In the cross with 'Maikonig', this ratio is modified by an epistatic effect, in which resistant masks the necrotic effect. This suggests that a different allele of the gene or a second necrotic gene is involved. An $\mathrm{F}_{2}$ population of 'Maikonig' $x$ 'Prizehead' was grown and inoculated with LMV. All plants in the $\mathrm{F}_{2}$ were necrotic; therefore necrosis in 'Maikonig' is due to another allele at the necrotic locus. The gene is named Necrotic- 1 . The allele in 'Maikonig' is named Necrotic $-1^{m}$, where $m$ stands for 'Maikonig'. The allele in 'Prizehead' is named
Necrotic $-1^{p}$, where $\mathrm{p}$ stands for 'Prizehead'. This nomenclature is described in Robinson et al. (1983).

Although the severity of the necrosis on 'Deer's Tongue' was similar to that found on 'Prizehead', subsequent growth of 'Deer's Tongue' was severely retarded, with no apparent recovery for at least 10 weeks subsequent to inoculation. 'Prizehead' began a recovery period after about 6 weeks. Therefore, the allele in 'Deer's Tongue' may be different. Parental, $F_{1}, F_{2}$, and $F_{3}$ families from the two recovery types in the first $F_{2}$ population were regrown. The results were not clear-cut; apparent segregation occurred in both sets of families, suggesting the possibility of quantitative inheritance.

Results herein indicate the need for further investigation of genetically controlled necrotic responses to LMV. Also the survey conducted of the occurrence of this reaction in various other cultivars showed that the severity of the necrotic reaction varied among the cultivars, suggesting the presence of additional genes or alleles (data not presented). Some of these cultivars are related to each other or to the cultivars discussed in this paper, so there are probably fewer alleles than cultivars. It appears the genetics of necrotic reaction to lettuce mosaic virus is complex.

\section{Literature Cited}

Bjorling, K. 1966. Virus resistance problems in plant breeding. Acta Agr. Scandinavica, Suppl. 16:119-136.

Couch, H.B. 1955. Studies on seed transmission of lettuce mosaic virus. Phytopathology 45:63-70.

Newhall, A.G. 1923. Seed transmission of lettuce mosaic. Phytopathology 13:104-106.

Pink, D.A.C., D. Kostova, and D.G.A. Walkey. 1992. Differentiation of pathotypes of lettuce mosaic virus. Plant Pathol. 41:5-12.

Redondo, E., R. Krause-Sakate, S.-J. Yang, H. Lot, O. Le Gall, and T. Candresse. 2001. Lettuce mosaic virus pathogenicity determinants in susceptible and tolerant lettuce cultivars map to different regions of the viral genome. Mol. Plant-Microbe Interactions 14:804-810.

Robinson, R.W., J.D. McCreight, and E.J. Ryder. 1983. The genes of lettuce and closely related species. Plant Breeding Rev. 1:267-293.

Ryder, E.J. 1968. Evaluation of lettuce varieties and breeding lines for resistance to common lettuce mosaic. U.S. Dept. Agr. Bul. 1391.

Ryder, E.J. 1970. Inheritance of resistance to common lettuce mosaic. J. Amer. Soc. Hort. Sci. 95:378-379.

Von der Pahlen, A. and J. Crnko. 1965. Lettuce mosaic virus (Marmor lactucae Holmes) in Mendoza and Buenos Aires. Rev. Invest. Agropecu., Ser. 5, No. 4:25-31.

Zink, F.W., J.E. Duffus, and K.A. Kimble. 1973. Relationship of a nonlethal reaction to a virulent isolate of lettuce mosaic virus and turnip mosaic susceptibility in lettuce. J. Amer. Soc. Hort. Sci. 98:41-45. 